\title{
A TECHNOLÓGIAORIENTÁLT START-UP CÉGEK LEHETŐSÉGEI ÉS KORLÁTAI AZ IPAR 4.0 KORSZAKÁBAN - KÉRDÖÍVES FELMÉRÉS ALAPJÁN
}

\section{THE POSSIBILITIES AND LIMITS OF TECHNOLOGY-ORIENTED STARTUPS UNDER INDUSTRY 4.0 -}

\author{
A SURVEY-BASED STUDY
}

\begin{abstract}
Alig jelentek meg az első jelek a világgazdaságot megrázó 2008-as gazdasági válságból való kilábalásról, a technológiailag élen járó országokban máris új forradalom robbant ki. A Németországban 2011-ben elfogadott „Industrie 4.0” kezdeményezést szinte azonnal követte az USA „Advanced Manufactured Partnership” programja, Kína 2015-ben bejelentett, a termelőszektort megújító „Made in China 2025”, illetve Olaszország „Industria 2016” víziója. Japán 2018-ban bejelentett - sokkal inkább már a negyedik ipari forradalomhoz kapcsolható - "Society 5.0" stratégiája egyrészt jelzi a negyedik ipari forradalom romboló és építő hatását, másrészt, hogy az új technológiák a társadalom és a gazdaság valamennyi területét megálíthatatlanul át fogják alakítani. Az Ipar 4.0 stratégia kibontakozása Európa több országában egybe esik a start-up ökoszisztémák tudatos kormányzati fejlesztésével, amelynek vállalkozásai egyszerre hordozói és elszenvedői is a változásoknak. A technológiaorientált start-up (hazai elnevezés szerint: korai fázisú) cégeknek nem csupán saját működésük létjogosultságát kell bizonyítaniuk, hanem - ezen túlmenően - támogatniuk kell a vállalati szektor átalakulásának komplex folyamatát. A kutatás során hazai, technológiai inkubátorok általi kockázatitőke-befektetésben részesült korai fázisú cégek, valamint müködő kisvállalkozások körében végzett kérdőíves felmérés formájában vizsgálta a szerző, hogyan és miben látják az Ipar 4.0 lényegét, ebben milyen eltérések figyelhetők meg a hagyományos cégekhez képest, illetve növekedési stratégiáik megvalósítását milyen menedzsmenttevékenységekkel látják biztosítottnak.
\end{abstract}

Kulcsszavak: ipari szervezetek, makroökonómia, iparpolitika, iparosítás

Soon after the first signs of recovery from the world economic depression of 2008 were recognized, technologically advanced economies have faced a new revolution. The "Industrie 4.0" initiative declared by Germany in 2011 was soon followed by the "Advanced Manufactured Partnership" program of the U.S., as well as by the "Made in China 2025" initiative for the advancement of the productive sector launched by the People's Republic of China and the "Industria 2016" vision of Italy. The "Society 5.0" strategy of Japan announced in 2018 symbolizes both the destructing and the constructive power of the fourth industrial revolution which will result in a complete restructuring of all fields of economy and society. The evolution of Industry 4.0 is parallel to the conscious efforts of many European governments to develop their own start-up ecosystems. These start-ups face significant challenges, but at the same time, they are the means to support changes. Technology-oriented start-up companies (also referred as early stage start-ups in Hungary) are not only expected to prove their own reason for existence, but should also support the complex changes of the corporate sector. This paper is based on a survey among early stage start-up companies, having received angel investment from technology incubators. The survey has focused on how these start-ups see of the significance of Industry 4.0, what differences are evident compared to traditional companies, and what management competencies are thought to be required to realize their growth strategy.

Keywords: industrial organization, macroeconomics, industrial policy, industrialization

Finanszírozás/Funding:

A kutatás az EFOP-3.6.2-16-2017-00007 pályázat keretében valósult meg.

\section{Szerző/Author:}

Dr. Halmosi Péter, egyetemi docens, Szegedi Tudományegyetem Gazdaságtudományi Kar Pénzügyek és Nemzetközi Gazdasági Kapcsolatok Intézete (halmosi@eco.u-szeged.hu)

A cikk beérkezett: 2019. 04. 18-án, javítva: 2019. 07. 22-én, elfogadva: 2019. 08. 07-én.

This article was received: 18.04.2019, corrected: 22.07.2019, accepted: 07.08.2019. 
A z Ipar 4.0 hatásának vizsgálata során fontosnak tartjuk röviden áttekinteni annak jelentését, valamint megjelenését a vállalatok életében. Ahogy arra Nagy (Nagy, 2017; Nagy, 2019) rávilágít, az Ipar 4.0 a vállalati szektort a középpontba állító jelenség, szemben a negyedik ipari forradalommal, amely sokkal szélesebb fogalom. Az 1970-es években kirobbant, a számítástechnikát és az elektronikai ipart előtérbe helyező harmadik ipari forradalom, az 1990-es években az internet elterjedése, majd az évtized végén a „dotcom” válság olyan táptalajt hozott létre, amely ösztönzőleg hatott új iparágak, technológiák megszületésének, végső soron mind a negyedik ipari forradalom, mind pedig az Ipar 4.0 stratégia megjelenésének.

Bár a hagyományos ipar teljesítményének növelése, a folyamatok racionalizálása létező igény, manapság az Ipar 4.0 jelentése nem korlátozódik a termelésre, az eszközök, termékek, szolgáltatások hálózatba kapcsolására, ahogyan azt Hofmann és Rüsch (2017) tanulmányukban megfogalmazták. Bár az internet egyfajta hajtómotorja a vállalati folyamatoknak, lényege az emberek, gépek, vállalatok közötti folyamatos kommunikációra irányul (Brettel et al., 2014), így a fogalom nem korlátozódik az ipari digitalizáció témakörére.

Heynitz és társai (2016) és Baldassarre és társai (2017) szerint az Ipar 4.0 lényege a vállalat értékteremtő képességeinek integrálása a teljes értéklánc mentén. A változások lényege az együttmüködésre való törekvés és a nagy mennyiségű adat feldolgozása (Xie et al., 2016). Müller és társai (2017) ezen túlmenve a valós idejű intelligens, horizontális és vertikális rendszerek létrehozásában látják az Ipar 4.0 lényegét, Hermann és társai (2016) szerint pedig az Ipar 4.0 magában foglalja az értéklánc megszervezésének újfajta technológiáit és koncepcióit. Kovács (2017a, 2017b) ezen túlmutatóan már az információs és kommunikációs technológiáknak a korábbiaknál szélesebb formában történő felhasználását hangsúlyozza, aminek lényeges előzménye a harmadik ipari forradalom után az informatika és a telekommunikációs ágazatok közötti határok elhalványodása volt (Szalavetz, 2016). A közelmúltban történt változásoknak köszönhetően manapság a kommunikációs technológiák a civil és a kormányzati szektorokban éppúgy elterjedtek, mint az üzleti szektorban. Ezek a változások alapjaiban alakítják át a szervezetek felépítését, müködését, végső soron más szervezetekkel való kapcsolatait, valamint alkalmazott üzleti modelljeit (Prause, 2015).

Az Ipar 4.0 szervezetekre gyakorolt hatásai kapcsán Porter és társa (2014) a verseny és a termék jelentésének, fogalmának átalakulását emeli ki. Az Ipar 4.0 korában a vállalatoknak új technológiai infrastruktúrát kell felépíteniük maguk köré. Az előállított termék immár csak „fizikai komponenssé” válik, amihez további „okos” komponensek (szenzorok, chipek, adattároló eszközök, szoftverek, beágyazott rendszerek stb.), valamint kapcsolati elemek (portok, antennák, protokollok, hálózatok) illeszkednek (Porter et al., 2015). Ezek az elemek, illetve eszközök egy olyan technológiai hátteret hoznak létre, aminek segítségével az értéklánc szereplői által gyűjtött adatok más rendszerekkel integrálhatóvá válnak.
Az Ipar 4.0 korában megjelenő eszközök az adatgyűjtés folyamatának megváltozásán keresztül újragondolásra késztetik az értékteremtési folyamatot. Ennek előzménye az internethálózat kiépülése és elterjedése volt az 1990-es évek elején, ami lehetővé tette a koordináció és integráció erősödését mind az értéklánc mentén, mind pedig földrajzilag (Porter et al., 2014). Ez a változás mindazonáltal a termék fizikai megjelenését akkor még változatlanul hagyta. Az Ipar 4.0 egyik forradalmi újítása - a korábbi forradalmakkal szemben - éppen az, hogy a termék fogalmát, fizikai megjelenését megváltoztatja, amit Porter és társa a termelékenység javulásával köt össze. A használati szokásokkal, a környezettel kapcsolatos adatok gyüjtése új funkciókon és kompetenciákon keresztül hozzáadott értéket teremt, ami:

- megnyilvánulhat a stabilabb, jobb hatásfokú müködésben, bizonyos, üzletileg releváns események előrejelzésében,

- kontrollfunkcióval ruházza fel a szereplöket, valamilyen funkció ki- vagy bekapcsolásával,

- javítja a teljesítményt, optimalizálja a müködést akár több tényező együttes figyelembevételével,

- az előző funkciók (monitoring - kontrolling - optimalizáció) együttes jelenlétével önálló helyi döntéshozatalt biztosít (Porter et al., 2014).

\section{Növekszik-e a termelékenység az Ipar 4.0 korában?}

A termelékenység növekedésével kapcsolatos várakozások azonban nem azonnal fognak jelentkezni, ahogyan arra Ogburn (1929) méltánytalanul elfeledett munkájában felhívta rá a figyelmet. A társadalmi-politikai-emberi tényezők konfigurációja - amit kulturális szövetnek nevezett el - tehetetlenséget visz a rendszerbe. Emiatt a tényleges átalakulás sokkal lassabb lesz, mint gondolnánk. Az Ipar 4.0 rendszerek éppen a nagy mennyiségü adat előállítása és felhasználása által képesek minőségi változásokat előidézni, amely folyamatok azonban - éppen a releváns összefüggések kiértékelhetősége és üzleti hasznosíthatósága okán - természetszerüen időigényesek.

Ezt alátámasztani látszanak az OECD Structural Business Statistics (ISIC Rev. 4) adatbázisának közelmúltbeli adatai is. 2012-2015 között csak Ausztria, Finnország, Belgium és Hollandia esetében növekedett a forgalom és az egy főre jutó hozzáadott érték a mikro- és kisvállalati szektorban. Nem volt érzékelhető változás Csehország, Lengyelország, Lettország és Magyarország esetében, de Németország, Olaszország, Franciaország esetében is stagnálás, illetve enyhe javulás volt csak megfigyelhetö, miközben az okoseszközök használatának aránya 20122017 között 11\%-kal, az ERP-k használati aránya pedig 16,3\%-kal nőtt 2009-2017 között nőtt a kisvállalati szektorban. Schwab (2016) szintén a GDP növekedési ütemének a természetes lassulását várja a következő évekre, aminek oka, hogy a fejlett országokban az életkor növekedése miatt a vásárlási szokások - ezáltal a „globális vásárlói kosár" tartalmának - átalakulása várható. Számításai szerint az USA-ban 2007-2014 között az alacsonyabb technológiai és innovációs hatékonyság miatt alacsonyabb volt a munka termelékenysége, vagyis a termelékenység 
növekedésével kapcsolatos várakozások egyelöre, úgy tünik, nem igazolhatók.

A termelékenység növekedését Sutton (2007) és Gorodnichenko et al. (2008) szerint sokkal tágabb kontextusban szükséges vizsgálni. A termelékenység a termék minőségével együttesen határozza meg a vállalatok versenyképességét. Ebben szerepük van a multinacionális vállalatok által létrehozott, országokon és iparágakon átnyúló értékláncoknak, a beáramló külföldi müködő tőkének, a vállalatok exportképességének, valamint az elérhető külső finanszírozási lehetőségeknek és azok költségeinek. Az innovációs teljesítményre komoly hatással van a vállalatok közötti tudástranszfer és a termékpiaci verseny (Gorodnichenko et al., 2010a; Gorodnichenko et al., 2010b). Ahogyan azt megállapítják, a hazai vállalatok technológiailag nem képesek az új tudáselemeket hatékonyan átvenni, így felzárkózni sem tudnak a külföldi versenytársaikhoz. Az Ipar 4.0 korában ugyanakkor megjelenik egy új vállalati szegmens, a technológiaorientált cégek csoportja, amely vállakozások a tudástranszfer új formáit, módszereit, csatornáit hozzák létre nap, mint nap. Fejlődésük, valamint a hagyományos gazdasági rendszerbe való integrálódásuk az értékközpontú müködés sikeressége miatt is fontos lesz a következő években.

\section{Felkészülés a hozzáadottérték-alapú működésre az Ipar 4.0 korszakában}

Az Ipar 4.0 a legújabb technológiai megoldások integrálásával egyrészt a hozzáadottérték-alapú müködést helyezik a vállalatok müködésének középpontjába, másrészt azonban folyamatos igazodást és alkalmazkodást kiváltva a szervezeti struktúrák fúzióját is eredményezik ${ }^{1}$.

Ennek következményeként a vállalaton belüli osztályok eltünésével, a beszállítók stratégiai partnerekké válásával csökkennek az iparágak, valamint a vállalatok közötti korlátok, erősödnek a szektorokon átívelő szövetségek, amik szintén felelősek a „hibrid” termékek megjelenéséért.

A változások először azokban az iparágakban válnak érzékelhetővé, amelyek termékeinek beruházási ciklusa rövidebb, ugyanakkor az egyes üzemeikbe nagy öszszegeket fektetnek be és a felhasznált nagymennyiségü alkatrészeivel kapcsolatos információkat pontosan nyilvántartják. Az autóipar és az orvosi müszergyártás mellett ezek a jellemzők az automatizálási célú beruházások iránt élénk aktivitást mutató építőiparban, elektronikai iparban, közlekedési és szállítási ágazatban is jelen vannak (PWC, 2016).

Az Ipar 4.0 azonban túlmutat az automatizálás nyújtotta vállalati költségcsökkentésen, illetve bevételnövelésen (PWC, 2016). A hozzáadottérték-alapú müködés valódi lényege nem az algoritmusok, illetve szenzorok integrálása, hanem a vertikális és horizontális értékláncok digi- talizációja és integrálása, a termék- és szolgáltatásnyújtás digitalizálása az üzleti modell digitalizálása és a fogyasztókkal való interakció optimalizálása. A jövőben az Ipar 4.0 szerint müködő vállalatok megjelenésére más iparágakban is számítani lehet, ahogy a verseny fokozódik, és a vállalatok és iparágak közötti határvonalak egyre inkább elmosódnak. A folyamat kezdeti időpontját a legtöbb vállalat meg tudja határozni saját üzleti céljai szerint, azonban a sikerhez vezető utak olyan technológiai döntéseken és technológiai trendekhez való igazodáson keresztül vezetnek, amelyek legfeljebb nagyvonalakban ismertek számos ágazatban. Az áttérés a vállalatok felső vezetésétől a következő lépéseket igényli (PWC, 2018a):

1. A vállalat digitális stratégiájának meghatározása. Egy 26 ország 1.155 termelővállalatának felső vezetőjével készített friss felmérés szerint a vállalatok 2/3-ának nincs víziója, stratégiája a digitális transzformáció és digitális kultúra támogatására.

2. A mesterséges intelligencia vállalati döntéshozatalba történő bekapcsolása. Az Ipar 4.0 megvalósításában élenjáró termelővállalatoknak mindössze $9 \%$-a használ ilyet.

3. A munkavállalók képzése az új technológiák használatára, a megnövekedett adattömeg kezelésére, feldolgozására és elemzésére. A felmérés szerint mindössze a termelővállalatoknál dolgozó munkavállalók 27\%-a rendelkezik a digitális átálláshoz szükséges - kreativitás, problémamegoldás, nyelvismeret, több feladat párhuzamos végzése, problémamegelőzés - kompetenciákkal.

Globálisan az Ipar 4.0 terjedési sebessége, ezáltal a vállalatok, iparágak, termékek és szolgáltatások átalakulásának folyamata eltérő lesz. Fontos előfeltétele a digitális átállás elősegítése, az időközi eredmények folyamatos értékelése, arra azonban Adamik és társa (2018) felhívja a figyelmet, hogy a legnagyobb kihívás az új kompetitív előnyök megtalálása és a változásokra való felkészülés lesz, amihez a jelenleg alkalmazott módszerek nem elégségesek2.

\section{A korai fázisú vállalkozások jelentősége az Ipar 4.0 komplex rendszerében}

A gazdasági fejlödés motorját jelentő innováció fö forrásai a jelentős $\mathrm{K}+\mathrm{F}$ kapacitásokkal rendelkező nagyvállalatok mellett a technológiaorientált kisvállalkozások (Makra, 2009, p. 176). Gazdasági szerepük az új munkahelyek teremtésében, innovációs és technológiai folyamatok gyorsításában és a gazdasági növekedés és szerkezetváltás elősegítésében érhető tetten. E cégek legfőbb versenyelönye az innovációs képesség, amivel új termékek, technológiák kifejlesztésén és piacra vitelén dolgoznak. Nem alkotnak homogén csoportot, gyakran még egymástól is különböznek, közös jellemzőjük ugyanakkor, hogy a külső környezetüket megtestesítő innovációs hálózatokon

\footnotetext{
${ }^{1}$ Heynitz és társai (2016) a jelenséget az evolúció és a konvergencia jelenlétén keresztül mutatják be.

${ }^{2}$ Az egyes iparágakra készített versenyképességet leíró mutatószámok nem képesek az ágazatokon átnyúló hatásokat mérni, így csak iparágon belüli következtetések levonására alkalmasak (Baldassarre et al., 2017).
} 
belül párhuzamosan számos fajta tudásátadási folyamatot indukálnak (Makra, 2009, p. 178).

A technológiai változásokban játszott kiemelkedő szerepük kulcsa az ún. kreatív rombolás. A nem létező vevői igényekre való koncentrálás vagy valamely piacvezető vállalkozás melletti piaci „niche” szerep megtalálása lehetővé teszi életben maradásukat, valamint az új technológia elterjesztését is. Egyszerre jellemző rájuk a „kihívó szerep", amelyben új technológiákat hoznak létre, valamint a „technológiatranszfer-szerep”, amelyben az újonnan létrehozott innovatív technológiákat a fogyasztói igényekhez igazítva eljuttatják a célcsoportokhoz. Mind létrejöttük, mind fejlődésük nagyban függ a kormányzati támogatások igénybevételi lehetőségeitől, az inkubátorházak, egyetemek, kutatóintézetek közelségétől, a tulajdonosi szerkezettől és az alapító csapat életkorától (Almus et al., 1999).

A korai fázisú cégek olyan átmeneti szervezetek, amelyek reprodukálható és skálázható üzleti modell keresésére jönnek létre (Blank, 2013). Ezek a cégek „olyan magas növekedési ütemű vállalatok, melyek magas kockázattal és bizonytalan végkimenetellel bírnak: megvan bennük a magas haszon ígérete, de ugyanakkor új ötletekkel, termékekkel, üzleti modellel és piacokkal kísérleteznek" (Magyarország Kormánya, 2016, p. 22). Vecsenyi (2011) szerint a start-up cégek sérülékeny kisvállalkozások, amelyek alapítóinak szeme előtt egy nagy vállalkozás képe lebeg.

A technológiaorientált korai fázisú cégek közös jellemzője a müszaki vagy tudományos, valamint üzleti sikerekre való együttes orientáltság, emiatt lényeges szereplői az Ipar 4.0 ökoszisztéma rendszerének. Müködésük számos sajátosságot mutat:

- gyakori az erős küldetéstudat a tulajdonosi kör részéröl,

- kiszolgálják a piacon működő vállalkozásokat új megoldásokkal, technológiákkal,

- küldetésükben gyakran jelenik meg más vállalkozások működési hatékonyságának növelése, üzleti folyamatok fejlesztése, új üzleti modellek, standardok kialakítása, meghonosítása (PWC, 2018b),

- működésük során a horizontális és vertikális értéklánc integrálásához sokkal kisebb mértékben járulnak hozzá a többi termelővállalathoz képest,

- egyaránt jellemző rájuk a hagyományos fogyasztói szokások elfogadása és azok gyors, drasztikus megváltoztatásának igénye,

- nem „kész” tereméket árulnak, így a fogyasztói bizalom elnyerésének problémája létbizonytalansági tényezőként jelenik meg számukra (Vecsenyi, 2011),

- elömozdítói a hagyományos gazdasági rend átalakulásának, foglalkozások és munkahelyek megszűnésének, valamint létrejöttének egyaránt.
A technológiaorientált korai fázisú vállalkozások segítésére létrejött ökoszisztémák komoly segítséget kapnak környezetüktől, aminek hatására 2015 után már nemcsak Nyugat-Európában, hanem Délkelet-Európában is élénkülni kezdett a korai fázisú közösség³

Belgiumban egy 30 start-up cégvezető körében végzett friss felmérés válaszadóinak 57\%-a úgy nyilatkozott, hogy a technológia érettsége kiemelt szerepet játszott a vállalkozás elindításában, 27\%-uk egy létező piaci igény és egy technológia ötvözésére alapozta az új cég elindítását, míg 17\%-uk konkrét piaci igények kielégítése miatt alapította meg a cégét (PWC, 2018b). A megkérdezett cégvezetők 83\%-a szerint vállalkozása a partnercégek müködési teljesítményét javítja, 70\%-a szerint pedig a múködési költségeit csökkenti.

Az Európai Bizottság friss, 700 start-up vállalkozásra kiterjedő elemzése arra hívja fel a figyelmet, hogy a startup cégek teljesítménye az idő előrehaladtával nem javul, gyakran az idősebb start-up cégeknek vannak rosszabb profitkilátásaik (European Commission, 2018, p. 4). Bár nemzeti szinten sok start-up cég jön létre, a nemzetközi piacokon való megjelenés aránya annak ellenére alacsony, hogy a vizsgált cégek több mint $2 / 3$-a digitális szolgáltatás nyújtásával foglalkozik.

\section{Az Ipar 4.0 megítélése a hazai korai fázisú vállalakozások körében}

A korai fázisú vállalkozások tulajdonosai jellemzően világos küldetéstudattal rendelkeznek, a globális trendeket, műszaki-technológiai újdonságokat saját működési területükön jól ismerik. Viszonylag kevés számú, rövid üzleti múltra visszatekintő olyan korai fázisú vállalkozás létezik jelenleg Magyarországon, akik körében átfogó felmérések ritkán készülnek. A szektorban gyakoriak a szervezeti formát, tulajdonosi kört, stratégiai célokat érintő változások, ugyanakkor a külső környezettel való kapcsolatokban megfigyelhetök mind a különbségek, mind pedig a hasonlóságok a már múködő hazai kisvállalkozásokhoz képest. A kutatás kiindulópontját az a hipotézis jelentette, hogy a hazai korai fázisú cégek az Ipar 4.0 fogalom- és keretrendszeréről éppúgy széles körű ismerettel rendelkeznek, mint a hagyományos hazai kisvállalkozások, nem ismert azonban, hogy az Ipar 4.0 által biztosított előnyökröl és gátló tényezőkről mennyiben gondolkodnak másként. Kevés kutatás foglalkozott eddig a vállalatok méretbeli növekedésével, folyamatainak racionalizálásával az Ipar 4.0 kontextusában (Bertelsmann Stiftung, 2015), annak ellenére, hogy a növekedési stratégiát támogató menedzsmenttevékenységek alapvetően meghatározzák a sikert.

A téma mélyebb tanulmányozása érdekében 2019 januárjában anonim kérdőíves felmérést végeztünk tíz hazai informális kockázatitőke-befektetésben részesült korai fázisú vállalkozás ${ }^{4}$ tulajdonosainak részvételével ${ }^{5}$.

\footnotetext{
${ }^{3}$ A South-East Europe Startup Report 2017 szerint 2017-ben Albániában 160, Horvátországban 500, Szerbiában 631, Szlovéniában 439 korai fázisú cég múködött.

${ }^{4}$ A befektetések összege 30-200 millió Ft között alakult, amelynek eredményeként a befektetök 8-24\% közötti tulajdoni részesedést szereztek a vállalkozásokban.

${ }^{5}$ Az állításokat a megkérdezett tulajdonosok egytől tízig terjedő skálán értékelhették (1=egyáltalán nem ért egyet, illetve 10=maximálisan egyet ért).
} 
Bár a korai fázisú vállalkozásokból napról napra egyre több van, a mintavételt a technológiai inkubátorok által tőkebefektetésben részesített korai fázisú cégekre korlátoztuk $^{6}$. A technológiai inkubátorok a hazai start-up ökoszisztéma kiemelt szereplőinek tekinthetők, befektetéseiket komoly szakmai akvizíció és projektértékelés előzi meg, a befektetést követően pedig átfogó vállalkozásmüködtetési ismeretek átadására törekednek. A 2017 után alakult vállalkozások közül három vállalkozás az ICT-szektorban, hat az egészségügyi szektorban, egy pedig a biotechnológiai szektorban müködik. A korai fázisú cégek mellett további tíz hazai müködő kisvállalkozást is bevontunk a vizsgálatba annak eldöntéséhez, hogy az Ipar 4.0-ról alkotott véleményekben megfigyelhetőek-e eltérések az Ipar 4.0-val kapcsolatos kérdésekben. ${ }^{7}$ A továbbiakban a fenti kutatási kérdésekre kapott eredményeket mutatjuk be.

\section{Hasonlóságok és különbségek az Ipar 4.0 megítélésében a hazai korai fázisú és hagyományos kisvállalkozások körében}

Mind a korai fázisú cégek, mind a müködő kisvállalkozások szerint az Ipar 4.0 bevezetésének legfontosabb akadályát a tőkeigényes beruházások jelentik. A kisvállal- kozások vezetői szerint ugyanakkor az Ipar 4.0 cél- és eszközrendszerének kiforrottsága is jelentős probléma. A korai fázisú cégek nagyobb mértékben gondolják azt, hogy az Ipar 4.0 képes lesz rávilágítani a szervezetek gyenge pontjaira, a működő kisvállalkozások szerint ugyanakkor nagyobb probléma, hogy az Ipar 4.0 miatt szükségessé váló változások menedzseléséhez nem áll rendelkezésre megfelelő tudás jelenleg a szervezetekben. A korai fázisú cégek ugyanakkor nagyobb kockázatot látnak az új rendszerek adatbiztonságában (1. táblázat).

A digitalizáció hatásaival kapcsolatosan a korai fázisú cégek leginkább az üzleti modell és a vállalkozások közötti kapcsolatok jellegének jelentős megváltozására számítanak, ugyanakkor szintén magas értéket kaptunk az intelligens (smart) eszközöknek a hozzáadottérték-teremtéshez való hozzájárulására. Az üzleti múlttal rendelkező vállalkozások vezetői az üzleti modell megváltozásának még a korai fázisú cégek vezetőinél is nagyobb jelentőséget tulajdonítottak. A vállalkozások közötti kapcsolatok jellegének megváltozására bár hasonlóan magas, de a korai fázisú cégek válaszaihoz képest alacsonyabb értéket adtak. Az üzleti modell megváltozása csak részben jelenti azt, hogy teljesen új típusú bevételi típusok kerülnek előtérbe (lásd

1. táblázat Az Ipar 4.0 bevezetésének legfontosabb akadályai

a korai fázisú cégek és a hagyományos kisvállalkozások szerint

\begin{tabular}{|l|c|c|}
\hline & $\begin{array}{c}\text { Átlagérték } \\
\text { korai fázisú } \\
\text { vállalkozások }\end{array}$ & $\begin{array}{c}\text { Átlagérték } \\
\text { hagyományos } \\
\text { kisvállalkozások }\end{array}$ \\
\hline Nem kellöen kiforrott, mit jelent az Ipar 4.0 cél- és eszközrendszere. & 6,6 & 7,2 \\
\hline $\begin{array}{l}\text { A vállalatok számára az Ipar 4.0 rövid távú költségeihez és üzleti kockázataihoz } \\
\text { képest nem mérhetőek fel megfelelően a hosszú távú elönyök. }\end{array}$ & 6 & 6,7 \\
\hline $\begin{array}{l}\text { Nem áll rendelkezésre megfelelő tudás ilyen horderejű változások menedzseléséhez } \\
\text { a szervezetben. }\end{array}$ & 6,3 & 6,9 \\
\hline $\begin{array}{l}\text { Nem áll rendelkezésre megfelelő tudás ilyen horderejü változások menedzseléséhez } \\
\text { a külső képzö, tanácsadó szektorban. }\end{array}$ & 6 & 6,4 \\
\hline $\begin{array}{l}\text { A piaci versenytársak ez irányú tevékenységének hiánya nem teremt ösztönzö } \\
\text { környezetet az Ipar 4.0 követéséhez. }\end{array}$ & 6,5 & 6,6 \\
\hline $\begin{array}{l}\text { Az Ipar 4.0 bevezetésének folyamata rávilágít olyan szervezeti gyengeségi pontokra, } \\
\text { amelyekkel a cégvezetők/tulajdonosok nem szeretnének szembesülni. }\end{array}$ & 6,9 & 5,7 \\
\hline $\begin{array}{l}\text { A piac állandó változása miatt ilyen komplex átalakítások csak rendkívül lassan } \\
\text { végezhetők el. }\end{array}$ & 5 & 5,9 \\
\hline $\begin{array}{l}\text { Az új „smart” eszközök komoly biztonsági kockázatnak teszik ki a vállalatokat } \\
\text { (pl. kibertámadás, adatok belső „lopása” stb.). }\end{array}$ & 6,2 & 5,4 \\
\hline Tökeigényes beruházásokat tesz szükségessé. & 7,4 & 8,0 \\
\hline $\begin{array}{l}\text { A költséges digitalizáció/automatizáció által elóállított többlet termékmennyiséget } \\
\text { nem tudják a cégek eladni a piacokon. }\end{array}$ & 5,2 & 4,2 \\
\hline
\end{tabular}

Forrás: kérdőíves felmérés

\footnotetext{
${ }^{6}$ A felmérés időpontjában a teljes mintát 81 vállalkozás alkotta.

${ }^{7}$ A megvizsgált tíz hazai kisvállalkozás átlagos életkora 13,9 év volt. Közülük kettő az ICT-ágazatban, kettő az egészségipari ágazatban, egy a biotechnológiai ágazatban, egy a hulladékgazdálkodási ágazatban müködött, további kettő az ipari automatizálással, egy élelmiszeripari termék gyártásával, egy pedig pénzügyi tanácsadással foglalkozott. 2017. évi beszámolók adatai szerint nettó árbevételük 73-1443 millió Ft között alakult. Kiválasztásuk során szempont volt, hogy rendszeresen végezzenek innovatív termék- vagy szolgáltatásfejlesztést.
} 
2. táblázat A digitalizáció hatása a vállalkozások működésére

\begin{tabular}{|c|c|c|}
\hline & $\begin{array}{l}\text { Átlagérték } \\
\text { korai fázisú } \\
\text { vállalkozások }\end{array}$ & $\begin{array}{l}\text { Átlagérték ha- } \\
\text { gyományos kis- } \\
\text { vállalkozások }\end{array}$ \\
\hline $\begin{array}{l}\text { A digitalizáció útjára lépő cégek életében a müködési modell („,business model”) na- } \\
\text { gyobb változásokon megy keresztül a következő öt évben, mint a digitalizációs tren- } \\
\text { deket nem követő vállalatoknál. }\end{array}$ & 8,9 & 8,8 \\
\hline A vállalatok stratégiai céljai markánssá, világossá, egyszerüen érthetővé válnak. & 5,9 & 6,9 \\
\hline A cégek életében a müködési modellje alapvető változáson megy keresztül. & 8,8 & 9,2 \\
\hline A cégek közötti üzleti kapcsolatok minőségi változáson mennek keresztül. & 9,6 & 8,4 \\
\hline A képzett munkaerő hiányának problémája alapvetően megoldódik. & 4,5 & 4,1 \\
\hline Lehetővé válik, hogy egy vállalat tudatosabban válassza ki vevőit, szállítóit. & 7,1 & 7,1 \\
\hline $\begin{array}{l}\text { A vállalatok adminisztrációs terhei csökkenni fognak, ami javítja a versenyképessé- } \\
\text { get. }\end{array}$ & 8 & 6,7 \\
\hline $\begin{array}{l}\text { A vállalatok adminisztrációs terhei növekednek, azonban a többlet adminisztráció ed- } \\
\text { dig nem látott piaci vagy termelési hatékonyságot eredményez majd. }\end{array}$ & 4,6 & 5,1 \\
\hline A vállalatok rövid távú finanszírozása biztonságosabb lesz, mint más vállalatoké. & 5,4 & 4,3 \\
\hline $\begin{array}{l}\text { A szellemi termékekhez kapcsolódó díjbevételek szerepe (pl. royalty, licencia) jelen- } \\
\text { tősen növekedni fog. }\end{array}$ & 6,5 & 5,6 \\
\hline A helyi társadalmi problémákra hatékonyabb megoldásokat fognak adni. & 6,1 & 4,0 \\
\hline $\begin{array}{l}\text { Az induló vállalkozások olyan információs, pénzügyi, humán stb. erőforrásokhoz ké- } \\
\text { pesek hozzáférni, amelyekkel versenyképességbeli hátrányukat csökkenteni képesek. }\end{array}$ & 8,4 & 7,1 \\
\hline $\begin{array}{l}\text { Elterjednek olyan intelligens (,smart”) informatikai eszközök, amelyek a fogyasztók } \\
\text { számára is jelentős hozzáadott értéket fognak biztosítani az elöállított termékekben, } \\
\text { szolgáltatásokban. }\end{array}$ & 9,3 & 8,8 \\
\hline
\end{tabular}

Forrás: kérdőíves felmérés

a royalty és licenciabevételek szerepe), a helyi társadalmi problémák megoldását pedig egyelőre nem valószínűsíti egyik vizsgált csoport sem (2. táblázat).

Bár az Ipar 4.0 alapjaiban változtatja meg a cégek müködését, más cégekkel való kapcsolatait, visszafogottabban nyilatkoztak mindkét célcsoport képviselői arról, hogy ez a folyamat a vállalati stratégiai célok markánssá, világossá, egyszerűen érthetővé válásával is jár-e majd. Egyértelmüen igazolódik, hogy a digitalizáció sikeressége új, kognitív képességeket, kreativitást, valamint fejlett szociális és érzelmi készséget igényel majd a munkavállalóktól (McKinsey, 2018). Az új technológiák mindazonáltal nem szüntetik meg, hanem újradefiniálják a munkaköröket (Szalavetz, 2016), ennek eredményeként a jövőben a standardizált munkafeladatokat gépek, a kreatívabb feladatokat pedig az újonnan képzett munkaerő fogja ellátni. Az adminisztrációs terhekben a korai fázisú cégek inkább látnak csökkenési potenciált, mint a müködő kisvállalkozások.

\section{A korai fázisú vállalkozások növekedési stratégiáinak és alkalmazott menedzsmenttevékenységeinek kapcsolata}

A korai fázisú vállalkozások számos növekedési stratégia és alkalmazott menedzsmenttevékenység kombinációja közül választhatnak. A növekedési stratégiák alapját az új termék kifejlesztése jelenti, amelyet - tesztelést és validálást követően - a vállalkozások folyamatosan új földrajzi célpiacokra igyekeznek eljuttatni. A terjeszkedés szükségessé teszi a kapacitások bővítését, valamint új típusú együttmüködési formák kialakítását. A hálózatokban való gondolkodás manapság már nemcsak a termékfejlesztés, hanem a tudás és a piac megszerzése, az üzleti folyamatok fejlesztése során is komoly potenciállal bír. Az új típusú üzleti modellek új típusú együttmüködéseket (pl. royalty, licenciamegállapodások, közös vállalat alapítása) is szükségessé tehetnek. Miközben a korai fázisú vállalkozások saját szervezetüket fejlesztik, folyamatosan keresik a kapcsolatokat a külső támogató szervezetekkel és elemzik versenytársaik tevékenységét. A növekedéssel kapcsolatos tevékenységek jellemzően szimultán jelennek meg ezeknek a vállalkozásoknak az életében, így erőforrásaikat a különféle menedzsmenttevékenységek között meg kell bontaniuk, hiszen az egyes stratégiákat az egyes tevékenységet eltérő módon képesek támogatni.

A vezetési kompetenciák segítségével a szervezet képes arra, hogy napi szinten kialakítsa és fenntartható módon megszervezze folyamatait, képes saját stratégia alkotására, és annak megvalósításának nyomon követésére alkalmas mérőszámok definiálására. A vállalat müködésére számos külső partnerszervezet hatással lehet, ezért a cég menedzsmentjének kell eldöntenie, mennyiben engedi, hogy e szervezetek véleménye hatással legyen a vállalkozásra. A siker szempontjából szintén meghatározó, hogy a növekedéshez szükséges tudással, egyéb pénzügyi, humán erőforrással rendelkeznek-e a tulajdonosok és azt hajlandóak-e a vállalat rendelkezésére bocsátani. A belső 
tranzakciós költségek az üzleti modell adaptációja miatt felmerülő költségeket jelentik, míg a külső tranzakciós költségek a növekedésnek a különböző földrajzi, iparági stb. sajátosságai miatt fellépő kiadásai.

A korai fázisú cégek fejlődését nagyban meghatározza, hogy a számos lehetséges növekedési stratégia és menedzsmenttevékenység közötti kapcsolatot hogyan alakítják ki. A két, egymással szorosan összefüggő kérdéskör közötti kapcsolatot mátrixelrendezés formájában a 3. táblázat mutatja be a kapott válaszok alapján ${ }^{8}$. földrajzi helyszínen való megjelenést, valamint a lobbi és külső szereplők elérését képesek biztosítani. Második legfontosabb terület a tudás mobilizálása, amely már - az új célcsoportok elérésén, az új földrajzi helyszínen való megjelenésen és a közös vállalat alapításán túl - a termékfejlesztést, a hálózati együttmüködéseket, valamint a licencia megállapodások kialakítását támogatja. Közel azonosan ítélik meg a pénzügyi és humán erőforrások mobilizálásának és az üzleti folyamatok reprodukálhatóságának problémáját a korai fázisú cégek tulajdonosai, amik

3. táblázat A növekedési stratégiák és az alkalmazott menedzsmenttevékenységek kapcsolata a korai fázisú cégek körében

\begin{tabular}{|c|c|c|c|c|c|c|c|c|}
\hline Menedzsmenttevékenységek & 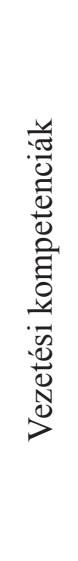 & 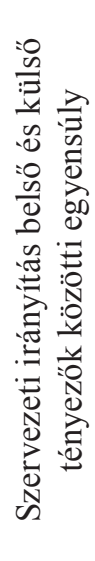 & 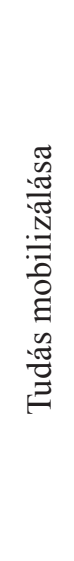 & 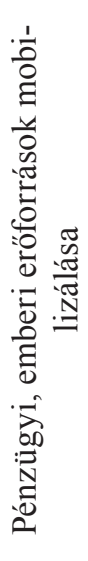 & 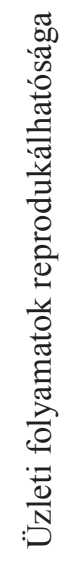 & 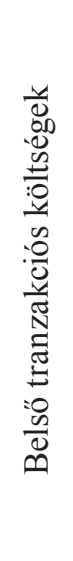 & 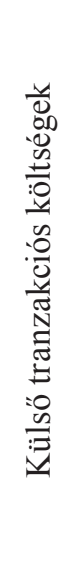 & 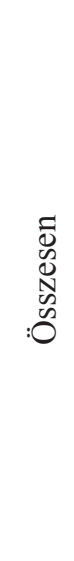 \\
\hline Kapacitásbővítés & 4,0 & 3,4 & 4,1 & 3,9 & 4,2 & 3,0 & 2,7 & 25,3 \\
\hline Új termék fejlesztése & 4,4 & 3,7 & 4,7 & 4,3 & 4,1 & 3,4 & 3,1 & 27,7 \\
\hline Új célcsoport elérése & 4,6 & 2,9 & 4,0 & 4,2 & 4,1 & 2,5 & 3,5 & 25,8 \\
\hline Földrajzi terjeszkedés & 4,6 & 3,4 & 4,0 & 4,4 & 4,4 & 2,8 & 3,7 & 27,3 \\
\hline Hálózati együttműködés & 4,4 & 3,2 & 4,3 & 3,7 & 3,4 & 2,9 & 3,6 & 25,5 \\
\hline Licenciaalapú együttmüködés & 3,5 & 3,5 & 4,2 & 2,8 & 3,4 & 2,8 & 3,9 & 24,1 \\
\hline Franchise-alapú együttmúködés & 4,1 & 3,7 & 4,0 & 3,4 & 4,1 & 3,2 & 3,8 & 26,3 \\
\hline Közös vállalat & 4,6 & 3,7 & 4,3 & 3,9 & 3,4 & 3,4 & 3,4 & 26,7 \\
\hline Versenytársak tevékenységének másolása & 4,1 & 3,0 & 3,4 & 3,3 & 3,6 & 2,8 & 3,1 & 23,3 \\
\hline Lobbitevékenység & 4,6 & 2,6 & 3,4 & 3,3 & 2,8 & 2,6 & 3,4 & 22,7 \\
\hline Technikai támogatás/segítség igénybevétele & 3,2 & 3,5 & 4,2 & 3,9 & 3,3 & 3,4 & 3,6 & 25,1 \\
\hline Összesen & 46,1 & 36,6 & 44,6 & 41,1 & 40,8 & 32,8 & 37,8 & \\
\hline
\end{tabular}

Forrás: kérdőíves felmérés

A növekedési stratégiák közül a korai fázisú cégek az új termék fejlesztését tekintik elsődlegesnek, amelyben a vezetési kompetenciák és a tudás mobilizálása jelenti a hajtóerőt. Ezt követi a földrajzi terjeszkedés, amelyben az elöbbi menedzsmenttevékenységeken túl a pénzügyi és humán erőforrások mobilizálásának, valamint az üzleti folyamatok reprodukálhatóságának jut vezető szerep.

A vizsgálatba bevont korai fázisú vállalkozások tulajdonosai szerint a menedzsmenttevékenységek közül legnagyobb hangsúlyt a vezetési kompetenciák kapják, amelyek elsődlegesen az új célcsoportok elérését, az új szintén leginkább a termékfejlesztési és terjeszkedési tevékenységeket támogatják.

\section{Összegzés}

Az Ipar 4.0 alapjaiban fogja átalakítani a vállalati szektor müködését a következő években, a vállalatok méretétől és iparágától függetlenül. Ahogy Jeff Immelt, a General Electric vezérigazgatója 2015-ben egy TV-interjúban megfogalmazta: „,minden vállalatnak szoftvercéggé kell válnia". A közeljövőben emiatt újra kell gondolni a hozzáadottérték-alapú müködés feltételeit és át kell alakí-

\footnotetext{
${ }^{8}$ A stratégiák és tevékenységek között vélt kapcsolatot a megkérdezett tulajdonosok egytől ötig terjedő skálán értékelhették (1=egyáltalán nem fontos, illetve $5=$ nagyon fontos).
} 
taniuk kapcsolataikat a horizontális és vertikális értéklánc valamennyi szereplőjével.

Bár az Ipar 4.0 jelentésével és jelentőségével mind a hagyományos, mind a korai fázisú vállalatok tisztában vannak, a folyamatot ösztönző és gátló tényezőkben helyenként eltérő álláspontok, illetve várakozások alakulnak ki, aminek hatásainak és következményeinek megértése további vizsgálatokat indokol. A korai fázisú vállalkozásokra az Ipar 4.0 további terhet ró azáltal, hogy a külső trendekhez való igazodás közepette növekedési stratégiáik és menedzsmenttevékenységeik tudatos, célzott összehangolására is szükség van a sikerek érdekében. A korai fázisú vállalkozások értékláncban betöltött szerepének fejlödését a kormányzatnak is aktív eszközökkel támogatnia kell. Szükség van olyan értékelési módszerek kidolgozására, amelyek segítségével a szektor teljesítménye a más vállalatokkal való kapcsolatok elmélyülésében, a tudástranszfer megvalósulásában is mérhetővé - és elismerhetővé - válik.

A korai fázisú technológiai cégek sérülékeny, mégis az egész gazdaság fejlődése, szempontjából fontos vállalati szegmenst jelentenek. Ahogy arra Gorodnichenko (2010b) rámutatott, a kis cégek esetében lényegesen nagyobb az innovációs tevékenység rugalmassága, mint a nagyobb cégek esetében. A gazdaságpolitikának emiatt nemcsak az új tudás létrehozását, hanem annak elterjedését is folyamatosan támogatnia és nyomon kell követnie. Figyelembe véve, hogy az Ipar 4.0 korában az óriási adattömegeket kezelő mesterségesintelligencia-rendszerek jönnek létre, ez akár elvezethet a klasszikus Greiner-modell szerinti konfliktuskezelés és -feloldás szekvencia alapjaiban történő megváltozásához is.

\section{Felhasznált irodalom:}

ABC Accelerator (2017). South-East Europe Startup Report 2017. https://abc-accelerator.com/wp-content/ uploads/.../south_east_startup_report_8.pdf. Letöltve: 2019. március $12^{-}$.

Almus, M. \& Nerlinger, E. A. (1999). Growth of new technology-based firms: Which factors matter? Small Business Economics, 13, 141-154.

Adamik, A. \& Nowicki, M. (2018). Preparedness of companies for digital transformation and creating a competitive advantage in the age of Industry 4.0. https://content.sciendo.com/downloadpdf/journals/ picbe/12/1/article-p10.xml

Baldassarre, F., Ricciardi, F., \& Campo, R. (2017). The advent of Industry 4.0 in manufactoring industry: Literature review and growth opportunities. https://hrcak. srce.hr/file/276313. Letöltve: 2019. március 6.

Bertelsmann Stiftung (2015). Scaling social impact in Europe. Quantitative analysis of national and transnational scaling strategies of 358 social enterprises. https:/www.bertelsmann-stiftung.de/fileadmin/files/ user_upload/BST_ScalingSocialImpactInEurope_final.pdf

Blank, S. (2013). Why the lean start-up changes everything. Harvard Business Review, 5. https://hbr.org/2013/05/ why-the-lean-start-up-changes-everything. Letöltve: 2019. március 12 .
Brettel, M., Friederichsen, N., Keller, M., \& Rosenberg, M. (2014). How virtualization, decentralization and network building change the manufacturing landscape: An Industry 4.0 perspective. International Journal of Mechanical, Industrial Science and Engineering, 8(1), 37-44. http://waset.org/Publication/9997144. Letöltve: 2019. március 5.

European Commission (2018). The startup Europe Ecosystem. Analysis of the Startup Europe projects and of their beneficiaries. JRC Technical Reports. https:// www.researchgate.net/publication/324170022_The Startup_Europe_Ecosystem_Analysis_of_the_Startup_Europe_projects_and_of_their_beneficiaries Letöltve: 2019 . március 8 .

Gorodnichenko, Y., Svejnar, J., \& Terrell, K. (2008). Globalization and innovation in emerging markets (NBER Working Papers Series 14481). http://www.nber.org/ papers/w14481 Letöltve: 2019. július 5.

Gorodnichenko, Y. \& Schnitzer, M. (2010a). Financial constraints and innovation: why poor countries don't catch up (NBER Working Papers Series 15792). http:// www.nber.org/papers/w15792 Letöltve: 2019. július 5.

Gorodnichenko, Y. \& Roland, G. (2010b). Culture, institutions and the wealth of nations (NBER Working Papers Series 16638). http://www.nber.org/papers/ w16368 Letöltve: 2019. július 5.

Hermann, M., Pentek, T., \& Otto, B. (2016). Design principles for industrie 4.0 scenarios. In: System Sciences (HICSS), 49th Hawaii International Conference on (pp. 3928-3937). IEEE. DOI: https://doi. org/10.1109/ HICSS.2016.488. Letöltve: 2019. március 5.

Heynitz, H.v., Bremicker, M., Amadori, D. M., \& Reschke, K. (2016). The factory of the future. Berlin, Németország: KPMG AG. https://assets.kpmg.com/content/ dam/ kpmg/es/pdf/2017/06/the-factory-of-the-future. pdf Letöltve: 2019. március 5.

Hofmann, E. \& Rüsch, M. (2017). Industry 4.0 and the current status as well as future prospects on logistics. Computers in Industry, 89, 23-34. DOI: http://dx.doi. org/10.1016/j.compind.2017.04.002. Letöltve: 2019. március 5.

Kovács, O. (2017a). Az Ipar 4.0 komplexitása I. Közgazdasági Szemle, 64(7-8), 823-851.

Kovács, O. (2017b). Az Ipar 4.0 komplexitása II. Közgazdasági Szemle, 64(9), 970-987.

Magyarország Kormánya (2016). Magyarország digitális startup stratégiája. http://www.kormany.hu/download /d/8c/e0000/Magyarorsz\%C3\%A1g\%20Digit\%C3\% A1lis\%20Startup\%20Strat\%C3\%A9gi\%C3\%A1ja.pdf Letöltve: 2019. március 7.

Makra, Zs. (2009). A technológiai vállalkozások létrejötte, növekedése és gazdasági szerepe a szakirodalom tükrében. Közgazdasági Szemle, 56(2), 176-186.

McKinsey\&Company (2018). Átalakuló munkahelyek: az automatizálás hatása Magyarországon. https://www. mckinsey.com/ /media/McKinsey/Locations/Europe $\% 20$ and $\% 20$ Middle $\% 20$ East/Hungary/Our $\% 20$ Insights/Transforming $\% 20$ our $\% 20$ jobs $\% 20$ automa- 
tion $\% 20 \mathrm{in} \% 20$ Hungary/Automation-report-on-Hungary-HU-May24.ashx Letöltve: 2018. december 12.

Müller, J., Dotzauer, V., \& Voigt, K. I. (2017). Industry 4.0 and its impact on reshoring decisions of German manufacturing enterprises. In: Supply Management Research (pp. 165-179). Wiesbaden, Germany: Springer, Gabler. DOI 10.1007/978-3-658-18632-6_8. Letöltve: 2019. március 5.

Nagy, J. (2017). Az Ipar 4.0 fogalma, összetevői és hatása az értékláncra. Budapest Corvinus Egyetem műhelytanulmány. HU ISSN 1786-3031 http://unipub.lib.unicorvinus.hu/3115/ Letöltve: 2018. december 12.

Nagy, J. (2019). Az Ipar 4.0 fogalma és kritikus kérdései Vállalati interjúk alapján. Vezetéstudomány, 50(1), 1426. DOI: 10.14267/ VEZTUD.2019.01.02 http://unipub. lib.uni-corvinus.hu/3869/1/VT_2019n1p14.pdf Letöltve: 2019. március 6.

OECD (2019). Structural Business Statistics. www.oecd. ord. Letöltve: 2019. március 6.

Ogburn, W.F. (1922). Social change with respect to culture and original nature. New York: B. W. Huebsch Inc. https://archive.org/details/socialchangewith00ogburich/ page/n3 Letöltve: 2019. június 30.

Porter, M. E. \& Heppelmann, J. E. (2014). How smart, connected products are transforming competition. Harvard Business Review, 92(11), 64-88. Letöltve: 2018. december 12.

Porter, M. E. \& Heppelmann, J. E. (2015). How smart, connected products are transforming companies. Harvard Business Review, 93(10), 96-114.

Prause, G. (2015). Sustainable business models and struc- tures for Industry 4.0. Journal of Security and Sustainability Issues 5(2), 159-169. DOI: http://dx.doi. org/10.9770/jssi.2015.5.2(3)

PWC (2016). Industry 4.0: Building the digital enterprise. https://www.pwc.com/gx/en/industries/industries-4.0/ landing-page/industry-4.0-building-your-digital-enterprise-april-2016.pdf Letöltve: 2019. március 5.

PWC (2018a). Global Digital Operations Study 2018 - How industry leaders build integrated operations ecosystems to deliver end-to-end customer solutions. https:// www.strategyand.pwc.com/media/file/Global-DigitalOperations-Study_Digital-Champions.pdf Letöltve: 2018. december 12.

PWC (2018b). Industry 4.0: The perspective of start-ups and scale-ups in Belgium. https://www.pwc.be/en/ documents/20181022-industry-4-0-report-starupsscale-ups.pdf Letöltve: 2018. december 12.

Schwab, K. (2016). The fourth industrial revolution. New York: World Economic Forum. Crown Publishing.

Sutton, J. (2007a). Quality, trade and the moving window: The globalization process. The Economic Journal, 117(524), 469-498, https://doi.org/10.1111/j.14680297.2007.02119.x Letöltve: 2019. június 30.

Szabó, Zs. R., Horváth, D., \& Hortoványi, L. (2019). Hálózati tanulás az ipar 4.0 korában. Közgazdasági Szemle, 66(1), 72-94.

Szalavetz, A. (2016). Az ipar 4.0 technológiák gazdasági hatásai - Egy induló kutatás kérdései. Külgazdaság, 60(7-8), 27-50.

Vecsenyi, J. (2011). Kisvállalkozások inditása és müködtetése. Budapest, Magyarország: Perfekt Kiadó. 